\title{
Association of Between Heavy Metal and Trace Element Levels in Blood and Cervical Mucus with Female Infertility
}

\author{
Kan ve Servikal Mukusta Ağır Metal ve \\ Eser Element Düzeyleri ile \\ Kadın İnfertilitesi İlişkisi
}

\author{
Halil ILGIN, MD, Msc, ${ }^{a}$ \\ Hikmet HASSA, MD, Prof., ${ }^{b}$ \\ Ahmet KARATAȘ, MD, Assis.Prof., \\ Salih KAHRAMAN, MD, Msc, ${ }^{d}$ \\ Bade ILGIN, MD, Msc \\ ${ }^{a}$ Clinic of Obstetrics and Gynecology, \\ Bahçe State Hospital, \\ ${ }^{e} \mathrm{Clinic}$ of Obstetrics and Gynecology, \\ Osmaniye State Hospital, Osmaniye \\ ${ }^{b}$ Department of \\ Obstetrics and Gynecology, \\ Eskişehir Osmangazi University \\ Faculty of Medicine, Eskişehir \\ 'Department of \\ Obstetrics and Gynecology, \\ Düzce University Faculty of Medicine \\ Düzce \\ ${ }^{\mathrm{d} C l i n i c}$ of Obstetrics and Gynecology, \\ Tokat State Hospital, Tokat
}

Geliş Tarihi/Received: 29.09 .2011 Kabul Tarihi/Accepted: 27.01.2012

Yazışma Adresi/Correspondence: Ahmet KARATAŞ, MD, Assis.Prof. Düzce University Faculty of Medicine, Department of Obstetrics and Gynecology, Düzce, TÜRKIYE/TURKEY akaratas1973@hotmail.com

\begin{abstract}
Objective: Infertility affects $10-15 \%$ of couples during the reproductive period. Ovulatory disorders are more common in younger women whereas unexplained infertility occurs more commonly in older women. Recently, many environmental agents, such as cigarettes, alcohol, heat, electromagnetic energy and radiation have been shown to have negative effects on the reproductive system. Environmental factors and exposure to heavy metals change fertility patterns in adults by affecting germ cell maturation, fertilization and the endocrine system. We aimed to investigate the effect of trace elements and heavy metals in blood and cervical mucus on female infertility. Material and Methods: Study was performed with 50 women: Infertile $(\mathrm{n}=35)$ and controls $(\mathrm{n}=15)$. Blood and cervical mucus samples were collected to measure $\mathrm{Zn}, \mathrm{Cu}, \mathrm{Cd}$, and Pb levels. Results: Mean blood plasma and cervical mucus $\mathrm{Zn}, \mathrm{Cd}$, and $\mathrm{Cu}$ levels in the infertile group were significantly lower than those in the control group. Whole blood $\mathrm{Pb}$ level was higher in the infertile group compared to the control group. Although blood Cd level tended to be higher in smokers and cervical mucus $\mathrm{Cd}$ level tended to be lower in controls, neither of these difference were statistically significant. Conclusion: Lower levels of plasma and cervical mucus $\mathrm{Zn}$ and $\mathrm{Cu}$ were thought to result from higher levels of $\mathrm{Cd}$ and $\mathrm{Pb}$ in blood and cervical mucus. Abnormal levels of heavy metals in blood and cervical mucus may have adverse effects on the female reproductive function.
\end{abstract}

Key Words: Cervix mucus; metals, heavy; trace elements; infertility, female

ÖZET Amaç: İnfertilite, üreme çă̆ındaki çiftlerin \%10-15' ini etkilemektedir. İleri yaşlarda daha yaygın olarak açıklanamayan infertilite, genç kadınlarda ise ovulatuvar rahatsızlık gözlenmektedir. Son zamanlarda, sigara, alkol, 1sı, elektromanyetik enerji ve radyasyon gibi çok sayıda çevresel ajanın üreme sistemine olumsuz etkisi olduğu gösterilmiştir. Çevresel faktörler ve ağır metallere maruz kalma, germ hücre olgunlaşmasını, döllenmeyi ve endokrin sistemi etkileyerek erişkinlerde doğurganlık durumunu etkilemektedir. Bu çalışmada kan ve servikal mucusta eser elementlerin ve ağır metallerin kadın infertilitesi üzerine etkisini araştırmayı amaçladık. Gereç ve Yöntemler: Çalışma 35 infertil ve 15 kontrol, toplam 50 kadın ile gerçekleștirildi. $\mathrm{Zn}, \mathrm{Cu}, \mathrm{Cd}$ ve $\mathrm{Pb}$ düzeylerini ölçmek için kan ve servikal mucus örnekleri toplandı. Bulgular: Ortalama kan plazması ve servikal mucus $\mathrm{Zn}$, Cd, ve Cu düzeyleri infertil grupta kontrol grubuna göre anlamlı olarak düşüktü. Tam kan kurşun düzeyi infertil grupta kontrol grubundan daha yüksekti. Sigara içenlerde kan Cd düzeyi daha yüksek ve kontrol grubunda servikal mucus Cd düzeyi daha düşük olma eğiliminde olmasına rağmen, her iki farklılık da istatistiksel olarak anlamlı değildi. Sonuç: Plazma ve servikal mucus $\mathrm{Zn}$ ve $\mathrm{Cu}$ düzeylerinin daha düşük olması, kan ve servikal mukusta Cd ve Pb’un daha yüksek olmasından kaynaklandığını düşündürmektedir. Kan ve servikal mukusta ağır metallerin anormal düzeyinin kadın üreme fonksiyonu üzerine olumsuz etkisi olabilir.

Anahtar Kelimeler: Servikal mukus; metaller, ağır; eser elementler; infertilite, kadın doi: 10.5336/medsci.2011-26725

Copyright $@ 2012$ by Türkiye Klinikleri
Turkiye Klinikleri J Med Sci 2012;32(4):1032-8 
-nfertility affects $10-15 \%$ of couples during the reproductive period. ${ }^{1}$ Ovulatory disorders are more common in younger women, whereas unexplained infertility occurs more commonly in older women. Ovulatory (15\%), tuboperitoneal (35\%), male factors (35\%), unexplained (10\%), and both male and female factors (35\%) are causes of infertility. ${ }^{2}$ Unexplained infertility is a diagnosis introduced by excluding other causes, and the prevalence ranges from 5 to $37 \%$ in different populations. ${ }^{3}$ Recently, many environmental agents, such as cigarettes, alcohol, heat, electromagnetic energy and radiation have been shown to have negative effects on the reproductive system. Environmental factors and exposure to heavy metals change fertility patterns in adults by affecting germ cell maturation, fertilization and the endocrine system. ${ }^{4,5}$ Not only the type of material, but also the exposure time determines the effects of these factors on reproductive health. Heavy metals may affect ovulation and cause abnormal sperm production based on their type, exposure duration and severity. ${ }^{6,7}$

Animal studies indicate a strong relationship between fertility and a lack of $\mathrm{Cu}$ and $\mathrm{Zn}$. Selenium and $\mathrm{Zn}$ prevent damage from toxic metals such $\mathrm{Cd}$ and Co. ${ }^{8,9}$ Cadmium and $\mathrm{Zn}$ can replace other metals in many vital enzymatic reactions and prevent function. ${ }^{10}$ Lead and Cd cause glutathione exhaustion and deterioration in the balance of free radicals. Zinc provides protection against $\mathrm{Pb}$ and $\mathrm{Cd}$ with its antioxidant properties.

Although numerous studies have demonstrated effects of trace elements and heavy metals on human health, their effects on female fertility have not been fully explained. In contrast to genetic causes, environmental and lifestyle factors causing poor fertility are treatable and preventable. Cervical and mucus factors should be considered when investigating causes of infertility. In this study, we measured the levels of $\mathrm{Zn}, \mathrm{Cu}, \mathrm{Cd}$, and $\mathrm{Pb}$ in whole blood (WB), blood plasma (BP), and cervical mucus (CM) of infertile women and compared with those of normal subjects.

\section{MATERIAL AND METHODS}

This study was performed at Eskisehir Osmangazi University School of Medicine, Department of Obstetrics and Gynecology, Center for Reproductive Health. Fifty cases (infertile group, $n=35$; control group, $\mathrm{n}=15$ ) were included after obtaining the permission of the Faculty Ethics Board. Exclusion criteria were impaired sperm parameters, users of hormonal contraceptives and intrauterine devices.

Gynecological history was reviewed, and physical and pelvic examinations were performed in all cases. Patients were evaluated by measuring follicle stimulating hormone (FSH), luteinizing hormone (LH), 17 $\beta$-estradiol, prolactin and thyroid stimulating hormone levels and obtaining a transvaginal ultrasound on days 2-5 of menstrual bleeding. Zinc, $\mathrm{Cu}, \mathrm{Cd}$ and $\mathrm{Pb}$ levels were measured in $\mathrm{WB}, \mathrm{BP}$, and $\mathrm{CM}$ in all cases. Blood samples were obtained from patients for WB (into EDTA-containing tubes) and BP [into heparin-containing tubes, followed by centrifugation $(2000 \times \mathrm{g}, 5 \mathrm{~min})$, and the supernatants were obtained].

Cervical mucous samples $(1 \mathrm{~mL})$ were collected with an intrauterine insemination apparatus (\#4502-B; Gynetics Medical, Hamont Achel, Belgium) connected to a tuberculin syringe before a gynecological examination on days 14-21 of the menstrual cycle. Samples were kept at $-20^{\circ} \mathrm{C}$ until analysis.

Heavy-metal analytical solutions were prepared by dilution in distilled water. Organics were removed by burning and applying acid. Cervical mucus samples were prepared by adding acid (100 $\mu \mathrm{L}$ concentrated $\mathrm{HNO}_{3}$; Merck, Whitehouse Station, NJ, USA) then diluting to a particular volume with distilled water. The burning procedure was applied initially to the WB samples at $600^{\circ} \mathrm{C}$ to constant weight. After the burning procedure, $0.5 \mathrm{~mL}$ of concentrated $\mathrm{HNO}_{3}$ and $0.5 \mathrm{~mL}$ of an acid mixture $\left(2 \% \mathrm{v} / \mathrm{v} \mathrm{HClO}_{4} / \mathrm{HNO}_{3}\right)$ were added. After this procedure, the samples were incubated in a water bath at $60^{\circ} \mathrm{C}$, and the analytical solutions were prepared. The final elemental analysis was performed 
with a polarized Zeeman atomic absorption spectrophotometer (Hitachi 180-70; Mountain View, CA, USA).

\section{STATISTICAL ANALYSES}

The SPSS software (SPSS 13, Chicago, IL, USA) was used for analyses. Descriptive parameters are presented as means \pm standard deviation, median $\left(25^{\text {th }}\right.$ $75^{\text {th }}$ percentiles) or as percentages. Two-sided $\mathrm{t}$-tests was used to analyze the differences in means of continuous variables in two groups when the variables were normally distributed. If variables were non-normally distributed, Mann-Whitney Utest was used. When there were more than two groups, one way ANOVA and Kruskall Wallis tests were used, respectively and Bonferroni correction was used for multiple comparisons $\left(\alpha^{*}=0.05 /\right.$ $3=0.017)$. Fisher's exact test (two-sided) and chisquare test were used when comparing the proportions between groups. Pearson correlation analysis was conducted to determine the association be- tween infertility parameters, heavy metals and trace elements. A p-value of $<0.05$ was considered significant.

\section{RESULTS}

Thirty (85.71\%) and 12 (80\%) housewives were in the infertile and control groups, respectively. The mean infertility period, weekly intercourse, weight, length, body mass index, and baseline FSH and LH levels were similar in patients and control subjects (Table 1).

Zinc and $\mathrm{Cu}$ levels in the BP and CM of the infertile group were lower than those in the control group. However, $\mathrm{Pb}$ levels in the WB were higher in the infertile group than those in control subjects. Lead levels in the CM and Cd levels in the WB were not significantly different between the groups. However, mean Cd level in the CM was higher in the infertile group compared to the control group (Table 1).

TABLE 1: Comparison of duration of infertility, weekly intercourse, weight, height, body mass index, basal FSH and $\mathrm{LH}$ level, $\mathrm{Zn}, \mathrm{Cu}, \mathrm{Pb}$ and $\mathrm{Cd}$ levels of WB, BP and CM of infertile patients with control group.

\begin{tabular}{|c|c|c|c|c|}
\hline & & $\begin{array}{l}\text { Infertile }(n=35) \text { (Average } \pm S D) \\
M(25-75 \text { percentiles) }\end{array}$ & $\begin{array}{l}\text { Control }(n=15) \text { (Average } \pm S D) \\
M(25-75 \text { percentiles) }\end{array}$ & $\mathrm{p}$ \\
\hline \multicolumn{2}{|l|}{ Age(year) } & $29.23 \pm 4.39$ & $28.67 \pm 4.97$ & 0.704 \\
\hline \multicolumn{2}{|c|}{ Duration of infertility (year) } & $7.71 \pm 4.73$ & --- & \\
\hline \multicolumn{2}{|c|}{ Weekly intercourse (n) } & $3 \pm 1.05$ & $2.86 \pm 0.64$ & 0.562 \\
\hline \multicolumn{2}{|c|}{ Housewife (n) } & (30) $85 \%$ & (12) $80 \%$ & 0.683 \\
\hline \multicolumn{2}{|l|}{ Smoker (n) } & (4) $11.4 \%$ & (4) $26.66 \%$ & 0.220 \\
\hline \multicolumn{2}{|l|}{ Weight (kg) } & $65.85 \pm 11.02$ & $67.66 \pm 11.77$ & 0.614 \\
\hline \multicolumn{2}{|l|}{ Height $(\mathrm{cm})$} & $160.57 \pm 5.95$ & $161.46 \pm 4.95$ & 0.582 \\
\hline \multicolumn{2}{|c|}{ BMI $\left(\mathrm{kg} / \mathrm{cm}^{2}\right)$} & $25.93 \pm 4.84$ & $25.52 \pm 4.99$ & 0.795 \\
\hline \multicolumn{2}{|c|}{$\mathrm{FSH}(\mathrm{mlU} / \mathrm{mL})$} & $6.82 \pm 3.33$ & $8.34 \pm 7.44$ & 0.453 \\
\hline \multicolumn{2}{|l|}{$\mathrm{LH}(\mathrm{mlU} / \mathrm{mL})$} & $5.55 \pm 3.47$ & $4.96 \pm 2.44$ & 0.490 \\
\hline \multirow{2}{*}{$\mathrm{Zn}$} & $\mathrm{BP} \mu \mathrm{g} / \mathrm{L}$ & $790.00(632-947)$ & $1560.00(862-1720)$ & 0.001 \\
\hline & $\mathrm{CM} \mathrm{mg} / \mathrm{L}$ & $10.90(7.12-13.82)$ & $32.40(15.15-34.05)$ & $<0.001$ \\
\hline \multirow{2}{*}{$\mathrm{Cu}$} & $\mathrm{BP} \mu \mathrm{g} / \mathrm{L}$ & $1408 \pm 455$ & $1785 \pm 537$ & $<0.001$ \\
\hline & $\mathrm{CM} \mathrm{mg/L}$ & $0.72 \pm 0.30$ & $1.32 \pm 0.49$ & $<0.001$ \\
\hline \multirow{2}{*}{$\mathrm{Pb}$} & WB $\mu \mathrm{g} / \mathrm{L}$ & $39.77 \pm 14.05$ & $29.17 \pm 16.05$ & 0.02 \\
\hline & $\mathrm{CM} \mu \mathrm{g} / \mathrm{L}$ & $17.26 \pm 5.05$ & $16.11 \pm 4.35$ & 0.420 \\
\hline \multirow{2}{*}{$\mathrm{Cd}$} & WB $\mu g / L$ & $1.1(0.93-1.25)$ & $0.76(0.60-1.38)$ & 0.127 \\
\hline & $\mathrm{CM} \mu \mathrm{g} / \mathrm{L}$ & $14.10 \pm 3.04$ & $11.47 \pm 3.22$ & 0.008 \\
\hline
\end{tabular}

BMI: Body mass index; FSH: Follicle stimulating hormone; LH: Luteinizing hormone; Zn: Zinc; Cu: Copper; Pb: Lead; Cd: Cadmium; BP: Blood plasma; CM: Cervical mucus; WB: Whole blood; SD: Standart Deviation; M: Median. 
TABLE 2: Comparison of $\mathrm{Zn}, \mathrm{Cu}, \mathrm{Pb}, \mathrm{Cd}$ levels of $\mathrm{WB}, \mathrm{BP}$ and $\mathrm{CM}$ of infertile subgroup patients with the control group.

\begin{tabular}{|c|c|c|c|c|c|c|c|}
\hline \multirow{3}{*}{$\begin{array}{c}\text { Trace } \\
\text { elements }\end{array}$} & & \multicolumn{4}{|c|}{ Types of Infertility } & \multirow[b]{2}{*}{ General $p$} & \multirow[b]{2}{*}{$\begin{array}{c}\text { Multiple } \\
\text { Comparison } p\end{array}$} \\
\hline & & $\begin{array}{c}\text { Ovulatory factor } \\
(n=12) \text { (Average } \pm S D) \\
M(25-75 \text { percentiles) }\end{array}$ & $\begin{array}{c}\text { Tubal factor } \\
(\mathrm{n}=10)(\text { Average } \pm \mathrm{SD}) \\
\mathrm{M}(25-75 \text { percentiles) }\end{array}$ & $\begin{array}{c}\text { Unexplained } \\
(n=13) \text { (Average } \pm S D) \\
M(25-75 \text { percentiles) }\end{array}$ & $\begin{array}{c}\text { Control } \\
(n=15) \text { (Average } \pm S D) \\
M(25-75 \text { percentiles) }\end{array}$ & & \\
\hline & Age (year) & $30 \pm 5.1$ & $31.1 \pm 3.58$ & $27.08 \pm 3.55$ & $28.67 \pm 4.97$ & 0.453 & \\
\hline \multirow{2}{*}{$\mathrm{Zn}$} & $\mathrm{BP} \mu \mathrm{g} / \mathrm{L}$ & 880 (715-910) & 840 (690-980) & 640 (607-952) & $1560(862-1720)$ & 0.009 & $\begin{array}{l}p_{1}=0.253 \\
p_{2}=0.186 \\
p_{3}=0.008\end{array}$ \\
\hline & $\mathrm{CM}$ mg/L & $11.2 \pm 3.59$ & $12.99 \pm 7.61$ & $10.07 \pm 4.34$ & $26.43 \pm 10.56$ & 0.008 & $\begin{array}{l}p_{1}<0.001 \\
p_{2}=0.004 \\
p_{3}=0.001\end{array}$ \\
\hline \multirow{2}{*}{$\mathrm{Cu}$} & $\mathrm{BP} \mu \mathrm{g} / \mathrm{L}$ & $1602 \pm 496$ & $1578 \pm 537$ & $1099 \pm 281$ & $1785 \pm 537$ & 0.002 & $\begin{array}{l}p_{1}=0.573 \\
p_{2}=0.452 \\
p_{3}=0.001\end{array}$ \\
\hline & $\mathrm{CM}$ mg/L & $0.64 \pm 0.26$ & $0.77 \pm 0.25$ & $0.75 \pm 0.37$ & $1.32 \pm 0.49$ & 0.001 & $\begin{array}{l}p_{1}<0.001 \\
p_{2}=0.004 \\
p_{3}=0.001\end{array}$ \\
\hline \multirow{2}{*}{$\mathrm{Pb}$} & WB $\mu \mathrm{g} / \mathrm{L}$ & $38 \pm 13$ & $40 \pm 10.4$ & $41 \pm 17$ & $29 \pm 16$ & 0.245 & \\
\hline & $\mathrm{CM} \mu \mathrm{g} / \mathrm{L}$ & $19 \pm 5.3$ & $17 \pm 5.1$ & $15.4 \pm 4.3$ & $16.1 \pm 4.3$ & 0.362 & \\
\hline \multirow[b]{2}{*}{$\mathrm{Cd}$} & WB $\mu \mathrm{g} / \mathrm{L}$ & $1.08 \pm 0.34$ & $1.13 \pm 0.43$ & $1.15 \pm 0.31$ & $1 \pm 0.54$ & 0.144 & \\
\hline & $\mathrm{CM} \mu \mathrm{g} / \mathrm{L}$ & $14.5 \pm 3.2$ & $14.5 \pm 3.2$ & $13.3 \pm 2.5$ & $11.4 \pm 3.2$ & 0.001 & $\begin{array}{l}p_{1}=0.012 \\
p_{2}=0.021 \\
p_{3}=0.124\end{array}$ \\
\hline
\end{tabular}

Zn: Zinc; Cu: Copper; Pb: Lead; Cd: Cadmium; BP: Blood plasma; CM: Cervical mucus; WB: Whole blood; SD: Standart Deviation; M: Median; $p_{1}$ : Between ovulatory factor and control groups, $\mathrm{p}_{2}$ : between tubal factor and control groups, $\mathrm{p}_{3}$ : between unexplained and control groups.

The infertile cases were divided into three subgroups: Ovulatory, tubal, and unexplained infertility. A comparison according to infertility type revealed that mean $\mathrm{Zn}$ and $\mathrm{Cu}$ levels in the $\mathrm{BP}$ of the unexplained infertility group were lower than those in the controls (Table 2). Furthermore, mean $\mathrm{Zn}$ and $\mathrm{Cu}$ levels in the $\mathrm{CM}$ were lower in all three infertile subgroups compared to the controls. In contrast, $\mathrm{Pb}$ levels in $\mathrm{BP}$ and $\mathrm{CM}$ were not significantly different among the groups. Cd level in CM was significantly higher in cases of ovulatory and tubal disorders compared to the control group.

Eight smokers (16\%) and 42 non-smokers (84\%) were also evaluated for $\mathrm{Zn}, \mathrm{Cu}, \mathrm{Cd}$ and $\mathrm{Pb}$ levels in blood and CM. Cd level in WB was higher in smokers, whereas it was lower in CM of smokers. No significant difference was observed when the $\mathrm{Zn}, \mathrm{Cu}, \mathrm{Cd}, \mathrm{Pb}$ levels in $\mathrm{WB}$ and $\mathrm{CM}$ were compared according to smoking status, infertility (primary vs. secondary) or age (20-29 vs. $30-42$ years).
The correlation analysis showed that Zn level in CM was significantly positively correlated with $\mathrm{Cu}$ level in $\mathrm{CM}$ ( $\mathrm{p}=0.002, \mathrm{r}=0.42)$, whereas a negative correlation was observed between the $\mathrm{Pb}$ level in $\mathrm{WB}$ and the $\mathrm{Zn}$ level in BP and CM ( $\mathrm{p}=0.042$, $\mathrm{r}=$ $-0.29 ; \mathrm{p}=0.008, \mathrm{r}=-0.37$, respectively). Negative correlations were detected between the $\mathrm{Zn}$ level in $\mathrm{BP}$ and the Cd level in WB and CM ( $\mathrm{p}=0.001, \mathrm{r}=-0.47$; $\mathrm{p}=0.001, \mathrm{r}=-0.55$, respectively; Figures 1,2 ) and between the $\mathrm{Zn}$ level in CM and the Cd level in WB $(\mathrm{p}=0.005, \mathrm{r}=-0.39)$.

\section{DISCUSSION}

This is the first study to show that $\mathrm{Cd}$ and $\mathrm{Pb}$ levels in CM and BP differ in infertile and fertile women. The results appear valid; most of the patients were housewives and had no history of direct exposure to chemicals or heavy metals.

Rükgauer et al. studied plasma trace element reference values in different age groups, and the plasma Zn level was $16.6 \mathrm{mmol} / \mathrm{L}(1085 \mathrm{mg} / \mathrm{L}) .{ }^{11} \mathrm{In}$ 


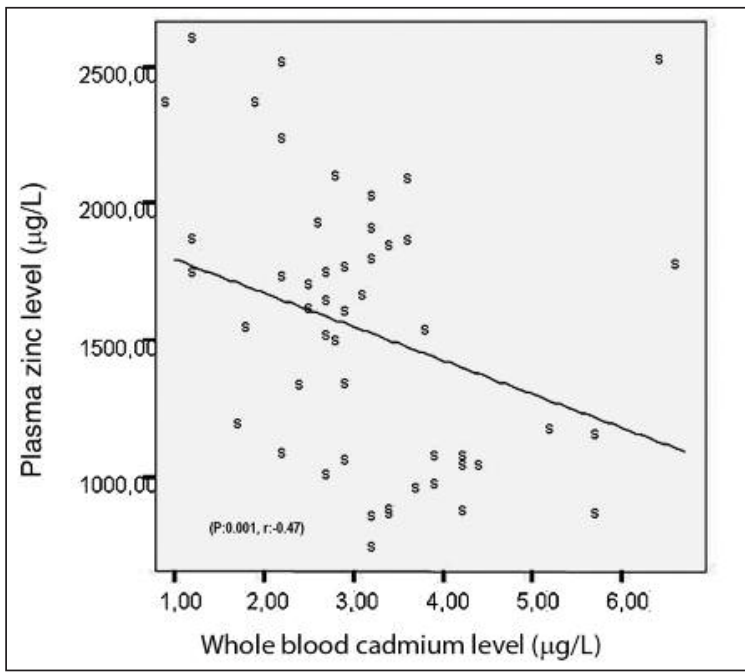

FIGURE 1: The correlation graphic between the zinc level of blood plasma and cadmium level of whole blood ( $\mathrm{p}=0.001, \mathrm{r}:-0.47$ ).

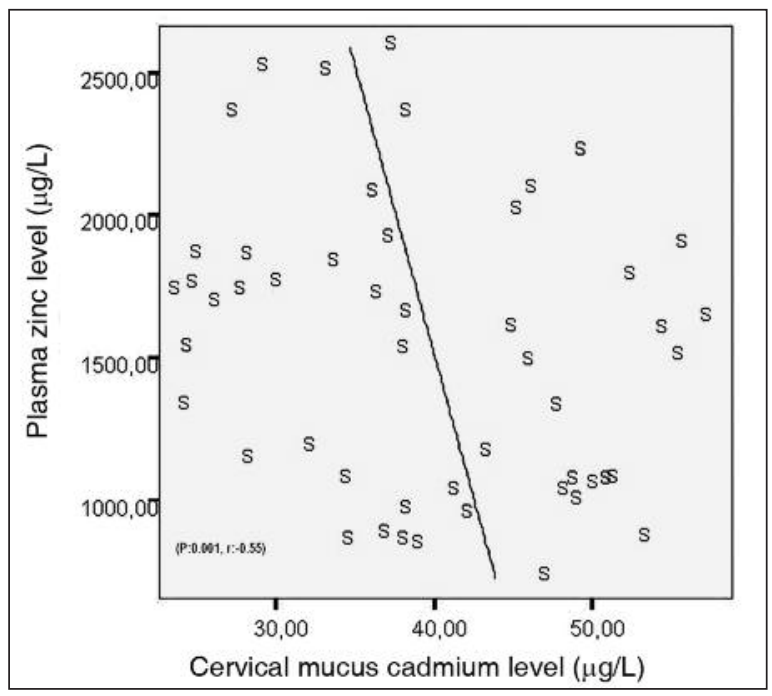

FIGURE 2: The correlation graphic between the zinc level of blood plasma and cadmium level of cervical mucus ( $p=0.001, r:-0.55)$.

our cohort, mean Zn levels in BP were 790 mg/L in infertile group and $1560 \mathrm{mg} / \mathrm{L}$ in the control group. Furthermore, mean plasma Zn levels were lower in the infertility subgroups than those in the control group, and a significant decrease was observed in the unexplained infertility group. Although a limited number of studies have reported Zn levels in BP, our findings are consistent with the literature. ${ }^{9,11-15}$ In previous studies, Zn levels were measured as the dry weight of CM. ${ }^{12,16}$ The only study on this topic was conducted by Chuang et al. in fertile patients, and $\mathrm{Zn}$ levels were 10.9 $\mathrm{mg} / \mathrm{L}$ and $32.4 \mathrm{mg} / \mathrm{L}$ in the CM of infertile and control groups, respectively. ${ }^{17}$ In that study, CM Zn levels were $11.2 \pm 3.59 \mathrm{mg} / \mathrm{L}$ in patients with ovulatory disorders, $10.0 \pm 4.3 \mathrm{mg} / \mathrm{L}$ in patients with unexplained infertility, and $12.99 \pm 7.6 \mathrm{mg} / \mathrm{L}$ in patients with tubal disorders. Again, all three groups had significantly lower CM Zn levels than those in a control group. In our study, the Zn level in the $\mathrm{CM}$ was lower $(<60 \mathrm{mg} / \mathrm{L})$ than that reported by Chuang et al. ${ }^{17}$

The $\mathrm{Cu}$ levels in BP tended to be lower in all three infertility subgroups than the control group, but a significant difference was observed only in the unexplained infertility group. The $\mathrm{Cu}$ levels in BP were consistent with the literature. ${ }^{11-13,15,18}$ In previous studies that examined $\mathrm{Cu}$ in $\mathrm{CM}$, the $\mathrm{CM}$ $\mathrm{Cu}$ levels were similar with those in the present study. ${ }^{17,19}$

Chang et al. found that average $\mathrm{Pb}$ levels in blood were $35.5 \pm 14 \mu \mathrm{g} / \mathrm{L}$ in infertile and $27.8 \pm 21$ $\mu \mathrm{g} / \mathrm{L}$ in fertile women. ${ }^{20}$ In the present study, the $\mathrm{Pb}$ levels in WB were $39.8 \pm 14 \mu \mathrm{g} / \mathrm{L}$ and $29.2 \pm 16$ $\mu \mathrm{g} / \mathrm{L}$ in the infertile and control groups, respectively. Lead levels in CM were similar in the infertile $(17.3 \pm 5 \mu \mathrm{g} / \mathrm{L})$ and control $(16 \pm 4.4 \mu \mathrm{g} / \mathrm{L})$ groups. Our findings were also similar to the blood $\mathrm{Pb}$ levels previously reported for infertile cases..$^{20,21}$ Cervical mucus $\mathrm{Pb}$ levels were 19.3 $\pm 5.3 \mu \mathrm{g} / \mathrm{L}$ in those with ovulatory disorders, $17.2 \pm 5.1 \mu \mathrm{g} / \mathrm{L}$ in those with tubal factors and $15.4 \pm 4.3 \mu \mathrm{g} / \mathrm{L}$ in those with unexplained infertility.

Cadmium levels in WB were $1.1(0.9-1.2) \mu \mathrm{g} / \mathrm{L}$ and $0.76(0.60-1.38) \mu \mathrm{g} / \mathrm{L}$ in the infertile and control groups, respectively. Whole blood Cd levels were $1.08 \pm 0.34 \mu \mathrm{g} / \mathrm{L}$ in patients with ovulatory dysfunction, $1.13 \pm 0.43 \mu \mathrm{g} / \mathrm{L}$ in patients with tubal factors and $1.15 \pm 0.3 \mu \mathrm{g} / \mathrm{L}$ in patients with unexplained infertility. McKelvey et al. reported that the mean blood Cd level was $0.79 \mu \mathrm{g} / \mathrm{L}$ in women. ${ }^{21}$ In present study, the CM Cd levels were $14.1 \pm 3 \mu \mathrm{g} / \mathrm{L}$ and $11.47 \pm 3.2 \mu \mathrm{g} / \mathrm{L}$ in the infertile and control groups, respectively. Cervical mucus $\mathrm{Cd}$ levels were $14.5 \pm 3.2 \mu \mathrm{g} / \mathrm{L}, 14.5 \pm 3.2 \mu \mathrm{g} / \mathrm{L}$ and 
$13.3 \pm 2.5 \mu \mathrm{g} / \mathrm{L}$ in women with ovulatory disorders, in women with tubal factor and in women with unexplained infertility, respectively. In a study performed in Taiwan, the CM-Cd level was $29.7 \pm 40.43 \mu \mathrm{g} / \mathrm{L}$, and no change in Cd levels was found according to age. ${ }^{17}$ Also in this study, no difference was detected for Cd levels in WB and CM according to age.

Previous reports showed no correlation between $\mathrm{Zn}$ and $\mathrm{Cu}$ levels in $\mathrm{BP}$ and $\mathrm{CM}$ or between $\mathrm{Zn}$ levels in BP and CM in reproductive women. ${ }^{12,22}$ A positive correlation was detected between blood levels of elements other than $\mathrm{Pb}$ and a transition of them into CM. BP and CM were significant in terms of $\mathrm{Zn}$ level, whereas $\mathrm{Cu}$ and $\mathrm{Cd}$ were not significant. The levels of $\mathrm{Zn}$ and $\mathrm{Cu}$ in $\mathrm{BP}$ reflected the level of these elements in CM. Zinc and $\mathrm{Cu}$ are required by organisms, and a positive correlation between these elements occurs. However, the harm caused by $\mathrm{Cd}$ and $\mathrm{Pb}$ is well known, and a negative correlation exists between $\mathrm{Zn}$ and $\mathrm{Cu}$, and $\mathrm{Cd}$ and $\mathrm{Pb}$. It may be concluded that while $\mathrm{Zn}$ and $\mathrm{Cu}$ have positive effects on fertility, $\mathrm{Cd}$ and $\mathrm{Pb}$ have negative effects. $\mathrm{Cd}$ and $\mathrm{Pb}$ levels were higher in infertile woman when compared to the control women; however, it is unclear what effect this had on infertility. Thus, larger prospective studies are needed in infertile women.

\section{CONCLUSION}

Zinc and $\mathrm{Cu}$ levels were lower and $\mathrm{Cd}$ levels were higher in infertile women compared to the control subjects. In particular, patients in the unexplained infertility subgroup had a significant association between $\mathrm{Zn}$ and $\mathrm{Cu}$ levels. Cadmium in $\mathrm{CM}$ was higher in infertile women compared to the controls, particularly in the ovulatory and tubal infertility subgroups. The effects of these elements must be considered in the etiology of infertility. More studies are needed to validate these novel findings.

\section{Acknowledgement}

This study was presented at the $15^{\text {th }}$ World Congress on In Vitro Fertilization, Geneva, Switzerland, April 19-22, 2009 as a poster presentation. The authors thank to Prof. Atilla Yildirim (lived in between 1951-2009) for his scientific advice and development of this study.
1. Mosher WD, Pratt WF. Fecundity and infertility in the United States: incidence and trends. Fertil Steril 1991;56(2):192-3.

2. Miller JH, Weinberg RK, Canino NL, Klein NA, Soules MR. The pattern of infertility diagnoses in women of advanced reproductive age. Am J Obstet Gynecol 1999;181(4): 952-7.

3. Aboulghar MA, Mansour RT, Serour GI, Amin Y, Ramzy AM, Sattar MA, et al. Management of long-standing unexplained infertility: a prospective study. Am J Obstet Gynecol 1999;181 (2):371-5.

4. Guillette LJ Jr, Moore BC. Environmental contaminants, fertility and multioocytic follicles: a lesson from wildlife? Semin Reprod Med 2006;24(3):134-41.

5. Sharara FI, Seifer DB, Flaws JA. Environmental toxicants and female reproduction. Fertil Steril 1998;70(4):613-22.

6. Choi SM, Yoo SD, Lee BM. Toxicological characteristics of endocrine-disrupting chemicals: developmental toxicity, carcinogenicity and

\section{REFERENCES}

mutagenicity. J Toxicol Environ Health B Crit Rev 2004;7(1):1-24.

7. Sinawat $\mathrm{S}$. The environmental impact on male fertility. J Med Assoc Thai 2000;83(8):8805.

8. Hidiroglou M. Trace element deficiencies and fertility in ruminants. J Dairy Sci 1979;62(8): 1195-206.

9. Anderson MB, Lepak K, Farinas V, George WJ. Protective action of zinc against cobaltinduced testicular damage in the mouse. Reprod Toxicol 1993;7(1):49-54.

10. Drbohlav P, Bencko V, Masata J, Bendl J, Rezácová J, Zouhar T, et al. [Detection of cadmium and zinc in the blood and follicular fluid in women in the IVF and ET program]. Ceska Gynekol 1998;63(4):292-300.

11. Rükgauer M, Klein J, Kruse-Jarres JD. Reference values for the trace elements copper, manganese, selenium, and zinc in the serum/plasma of children, adolescents and adults. J Trace Elem Med Biol 1997;11(2):928
12. Hagenfeldt K, Plantin LO, Diczfalusy E. Trace elements in the endometrium. 2. Zinc, copper and manganese levels in the endometrium, cervical mucus and plasma. Acta Endocrin 1973;72(1):115-26.

13. Iqbal AS, Shahidullah M, Islam MN, Akhter S, Banu S. Serum zinc and copper levels in the maternal blood and cord blood of neonates. Indian J Pediatr 2001;68(6):523-6.

14. Izquierdo Alvarez $\mathrm{S}$, Castañón SG, Ruata ML, Aragüés EF, Terraz PB, Irazabal YG, et al. Updating of normal levels of copper, zinc and selenium in serum of pregnant women. J Trace Elem Med Biol 2007;21(Suppl 1):49-52.

15. Benes B, Spěvácková V, Smíd J, Cejchanová $M$, Cerná $M$, Subrt $P$, et al. The concentration levels of $\mathrm{Cd}, \mathrm{Pb}, \mathrm{Hg}, \mathrm{Cu}, \mathrm{Zn}$ and $\mathrm{Se}$ in blood of the population in the Czech Republic. Cent Eur J Public Health 2000;8(2):117-9.

16. Daunter B, Chantler EM, Elstein M. Trace metals $(\mathrm{Cu}, \mathrm{Mn}, \mathrm{Zn}, \mathrm{Fe})$ sulphydryl and disulphide groups of cervical mucus. Contraception 1977; 15(5):543-52. 
17. Chuang IC, Lee PN, Lin TH, Chen GS. Determination of some elements in the cervical mucus of healthy Taiwanese women, by GF-AAS. Biol Trace Elem Res 2002;86(2): 137-43.

18. Soltan MH, Jenkins DM. Plasma copper and zinc concentrations and infertility. Br J Obstet Gynaecol 1983;90(5):457-9.

19. Randic L, Musacchio I, Epstein JA. Copper le- vels in cervical mucus of women with copperbearing and noncopper-bearing intrauterine devices. Biol Reprod 1973;8(4):499-503.

20. Chang SH, Cheng BH, Lee SL, Chuang HY, Yang $\mathrm{CY}$, Sung FC, et al. Low blood lead concentration in association with infertility in women. Environ Res 2006;101(3):380-6.

21. McKelvey W, Gwynn RC, Jeffery N, Kass D, Thorpe LE, Garg RK, et al. A biomonitoring study of lead, cadmium, and mercury in the blood of New York City adults. Environ Health Perspect 2007;115(10):1435-41.

22. Kaczmarek A, Robak-Chołubek D, Sowa I, Jakiel G. Comparison of the levels of copper, zinc and iron in cervical mucus and in blood serum of women of childbearing age. Ann Univ Mariae Curie Sklodowska Med 2004;59 (1):72-5. 
Copyright of Turkiye Klinikleri Journal of Medical Sciences is the property of Ortadogh Reklam Tanitim ve Yayincilik Turizm Egitim Insaat Sanayi ve Ticaret A.S. and its content may not be copied or emailed to multiple sites or posted to a listserv without the copyright holder's express written permission. However, users may print, download, or email articles for individual use. 